\title{
Anestesi i endring
}

For bare 15-20 år siden ble selv friske pasienter rutinemessig innlagt i sykehuset dagen før planlagte operative inngrep - for journalopptak, blodprøver og ofte EKG og røntgen thorax. Fullstendig faste også for drikke fra midnatt var regelen for alle, uavhengig av planlagt operasjonsstart. Pasienten ble fraktet i seng til operasjonsstuen av portør, både fordi sedvane tilsa det, men også fordi pasienten var utslått av premedikasjon. Ved ankomst fikk man gjerne benzodiazepin intravenøst, fulgt av datidens standard narkosemedikamenter: fentanyl, pancuronium, lystgass og isofluran. Pasienten ble intubert før operasjonsfeltet ble vasket og dekket, og deretter ble kirurgen tilkalt. Etter avsluttet kirurgisk inngrep tok det ikke sjelden over 30 minutter før pasienten var tilstrekkelig våken til at tuben kunne fjernes. Så lå pasienten gjerne i timevis på postoperativ avdeling med kvalme, delvis ufrie luftveier og inadekvat respirasjon som følge av resteffekter av medikamentene. Man ble tidligst skrevet ut av sykehuset dagen etter.

I dag møter pasienter for tilsvarende inngrep på en dagkirurgisk enhet kl 12 etter at de få timer tidligere har spist frokost hjemme (1). De spaserer selv inn og legger seg til rette på operasjonsbordet. Pasienten småprater mens operasjonsfeltet klargjøres og overvåkningsutstyr påmonteres, eller de gis et korttidsvirkende sedasjonsmiddel om de ønsker. Narkosen innledes når kirurgen står klar, og de ultrakorttidsvirkende medikamentene vi i dag benytter, muliggjør at pasienten presist og forutsigbart våkner nærmest idet siste sårstinget settes. De fleste flytter seg ved egen hjelp fra operasjonsbordet over i en hvilestol eller seng og får servert et lett måltid nærmest umiddelbart ved ankomst oppvåkningen. To-tre timer senere er de ofte kjekke nok til å reise hjem, blant annet fordi medikamentell forebygging av postoperativ smerte og kvalme er blitt iverksatt før og under inngrepet.

Disse endringene kan selvsagt ikke tilskrives anestesiologiske framskritt alene. Avgjørende er også forbedrede kirurgiske metoder, som omlegging til kikkehullskirurgi ved f.eks. kolecystektomi og hysterektomi. Vilje til nytenkning hos dem som planlegger virksomheten og hos alt involvert personale er også viktig. Like fullt er det slik at anestesiologiske nyvinninger og omlegginger har vært avgjørende for at man i det hele tatt har kunnet modernisere kirurgisk virksomhet (2). Vi har fått tilgang til medikamenter med færre bivirkninger og kortere virketid (3), og vi er blitt flinkere til å tilpasse dosene til den enkelte pasients behov og til den aktuelle kirurgiske intensiteten. For eksempel gjør vask av operasjonsfelt med intakt hud eller venting på kirurg ikke vondt og krever derfor ikke narkose. Tilleggsmedikamenter for å forebygge smerte og kvalme brukes nå rutinemessig. Resultatet er at pasientene i dag er mye kvikkere i hele det postoperative forløpet. Som en erfaren kollega uttrykte nylig: «Jeg finner jo ikke lenger tunge postoperative pasienter med ufrie luftveier å vise frem for studentene.»

Bildet er selvsagt også noe mer nyansert enn i beskrivelsen innledningsvis; ikke alle pasienter følger så greie forløp selv i dag. Hos noen pasienter kan ledsagende sykdommer, funksjonsinnskrenkning eller sosiale forhold gjøre at de slett ikke egner seg for å skrives inn og ut samme dag som de opereres. Det finnes selvsagt også en rekke operasjoner som heller ikke egner seg til å utføres dagkirurgisk, men slike grenser flyttes stadig (4). Det er imidlertid ingen ting i veien for at moderne anestesiologiske prinsipper også anvendes for inneliggende pasienter (5). Det kan gjelde enkle ting som å unngå unødig faste før og etter operasjonen, avstå fra medi- kamenter som gir unødig resteffekter og følge en gjennomtenkt plan for forebygging av smerter og kvalme.

Nettopp erkjennelsen av de endringene faget vårt har gjennomgått, er utgangspunktet for den artikkelserien som presenteres i dette og de tre påfølgende utgaver av Tidsskriftet. Serien motiveres av flere ønsker: En konsekvens av omleggingen av forløpet er at flere pasienter mottas direkte til operasjon basert bare på henvisning fra lege utenfor sykehuset. Det at henvisende lege har kjennskap til anestesiologiske vurderinger, kan øke sannsynligheten for at de opplysningene anestesiologen trenger for å kunne planlegge operasjonen, fremkommer. I en av artiklene gjøres det rede for nettopp dette (4). Temaserien gir også fagfellevurdert skriftlig materiale på norsk til støtte for undervisning. Men aller viktigst er kanskje den begeistringen vi føler for faget vårt og de endringene det - og vi har gjennomgått. Dette ønsker vi å vise frem for andre kolleger.

Endringene i anestesien og omleggingen av perioperative rutiner har ikke gått på bekostning av sikkerheten. Alvorlige skader som følge av anestesi er i dag heldigvis uhyre sjeldent (6). Like fullt er det betimelig å minne om at anestesi fremdeles har potensielt alvorlige konsekvenser. Generell anestesi eller narkose kan sammenliknes med en kontrollert intoksikasjon, der pasienten fratas evnen til selv å opprettholde helt nødvendige livsfunksjoner som frie luftveier, egen respirasjon og i noen tilfeller adekvat sirkulasjon. Kontrollen ligger $\mathrm{i}$ anestesipersonellets kunnskaper, ferdigheter og rutiner. Av og til møter man andre kolleger som ber anestesiologen lempe på krav til bemanning og utstyr under henvisning til at det planlagte inngrepet er så lite eller kortvarig. Men - på samme måte som det er like farlig å falle ned fra en kort som fra en lang flytur, er fallhøyden ved anestesi like stor uavhengig av prosedyrens lengde. Kravene til sikkerhet, slik de er nedfelt i Norsk standard for anestesi (7), gjelder uavhengig av prosedyrens lengde og overalt hvor anestesiologisk arbeid utføres.

\section{Siv Cathrine Høymork}

s.c.hoymork@medisin.uio.no

Siv Cathrine Høymork (f 1965) er ph.d. fagsjef i Legeforeningen og overlege ved anestesiavdelingen ved Sykehuset Asker og Bærum.

Oppgitte interessekonflikter: Ingen

\section{Litteratur}

1. Maltby JR. Fasting from midnight--the history behind the dogma. Best Pract Res Clin Anaesthesiol 2006: 20:363-78.

2. White PF, Kehlet H, Neal JM et al. The role of the anesthesiologist in fast-track surgery: from multimodal analgesia to perioperative medical care. Anesth Analg 2007; 104: 1380-96.

3. Ræder J, Høymork SC. Moderne farmakologiske prinsipper for intravenøs anestesi. Tidsskr Nor Legeforen 2010; 130: nr. 6.

4. Ræder J, Nordentoft J. Anestesi ved dagkirurgi. Tidsskr Nor Legeforen 2010; 130: nr. 7

5. Lassen K, Soop M, Nygren J et al: Consensus review of optimal perioperative care in colorectal surgery: Enhanced Recovery After Surgery (ERAS) Group recommendations. Arch Surg 2009; 144: $961-9$

6. Fasting S. Risiko ved anestesi. Tidsskr Nor Legeforen 2010; 130: nr. 5.

7. Norsk anestesiologisk forening, Den norske legeforening. www.nafweb.no/ index.php?option=com content $\&$ view=article \&id=56: standard \& catid=38: standarder\&Itemid=27 (8.2.2010) 